\title{
Improving Learning Outcomes in Theme 3 My Daily Tasks for Class II Students through the Kahoot Application
}

\section{Fajar Syahru Romadhon}

SD Negeri Margasari 03

fajarsyahrur061212@gmail.com

Article History

accepted 01/11/2020

approved 08/11/2020

published 15/11/2020

\begin{abstract}
The purpose of this research is to improve thematic learning outcomes through the Kahoot application. This research is a classroom action research (PTK) which was conducted in 3 cycles. The research was conducted in three cycles. Each cycle consists of four stages, namely planning, implementing, observing, and reflecting. This research was conducted on second grade students at SD Negeri Margasari 03, Margasari District, Tegal Regency with a total of 29 students. Research time was conducted from October to November 2020. The data collection technique used tests. Data analysis consisted of data reduction, data presentation, and conclusion drawing. Research shows the use of the Kahoot application can improve the learning outcomes of the theme 3 of my daily tasks in class II SD Negeri Margasari 03 Academic Year 2020/2021 as evidenced by the percentage of completeness of learning outcomes in cycle I, namely $76 \%$, in cycle II it increases to $83 \%$ and cycle III to $90 \%$.
\end{abstract}

Keywords: Theme 3, My learning Activity, Kahoot

\begin{abstract}
Abstrak
Tujuan Penilitian ini untuk meningkatan hasil belajar tematik melalui aplikasi Kahoot. Penelitian ini merupakan penelitian tindakan kelas (PTK) yang dilaksanakan dalam 3 siklus. Penelitian dilakukan dalam tiga siklus. Tiap siklus terdiri dari empat tahapan yaitu perencanaan, pelaksanaan, obsevasi, dan refleksi. Penelitian ini dilaksanakan pada siswa kelas II di SD Negeri Margasari 03 Kecamatan Margasari Kabupaten Tegal dengan jumlah siswa 29 siswa. Waktu Penelitian dilaksanakan pada bulan Oktober sampai dengan November 2020. Teknik pengumpulan data menggunakan tes. Analisis data terdiri dari reduksi data, penyajian data, dan penarikan kesimpulan. Penelitian menunjukkan penggunaan aplikasi Kahoot dapat meningkatkan hasil belajar tema 3 tugasku sehari- hari pada siswa kelas II SD Negeri Margasari 03 Tahun Pelajaran 2020/2021 yang dibuktikan dengan persentase ketuntasan hasil belajar siklus I yaitu $76 \%$, pada siklus II naik menjadi $83 \%$ dan pada siklus III menjadi $90 \%$.
\end{abstract}

Kata kunci: Tema 3, Tugasku sehari-hari, Kahoot

Social, Humanities, and Education Studies (SHEs): Conference Series https://jurnal.uns.ac.id/shes

p-ISSN 2620-9284

e-ISSN 2620-9292 


\section{PENDAHULUAN}

Pembelajaran daring di terapkan pada masa pandemi sebagai upaya pencegahan penyebaran covid-19. Pembelajaran daring membutuhkan sarana pendukung seperti laptop atau smartphone dan internet. Banyak permasalahan pembelajaran daring muncul karena tidak semua siswa memiliki smartphone, keterbatasan quota maupun kemampuan menggunakan teknologi. Meskipun demikian, guru tetap dituntut untuk dapat melaksanakan pembelajaran daring dengan menarik, menantang, menyenangkan, bermakna dan berdampak bagi siswa di kehidupan mendatang.

Pembelajaran daring pada SD Negeri Margasari 03 menggunakan aplikasi whatsapp group, karena aplikasi ini dianggap paling mudah digunakan. Namun dalam pembelajaran daring ini masih menemui beberapa kendala, diantaranya adalah pembelajaran daring belum maksimal karena masih banyak siswa malas megerjakan tugas, guru harus selalu mengingatkan untuk mengerjakan tugas dan masih banyak yang belum memahami materi sehingga hasil belajar siswa rendah.

Berdasarkan pengamatan selama pembelajaran daring, hanya beberapa siswa yang aktif dalam mengerjakan tugas daring. Sebagaimana yang terjadi pada pembelajaran yang sudah dilaksanakan, dari 29 siswa saat mengerjakan evaluasi, guru harus selalu mengingatkan untuk mengerjakan. Ketika siswa mengerjakan evaluasi daring ternyata hasil belajar tidak sesuai harapan. Nilai rata-rata peserta didik 67. Dari 29 siswa hanya 17 siswa yang mendapat nilai lebih atau mencapai KKM. Dengan demikan dapat dinyatakan bahwa ketuntasan belajar yang dicapai dalam pembelajaran baru mencapai $58 \%$.

Dari permasalahan tersebut, diperlukan upaya guru untuk mencari alternatif pemecahan masalah yaitu dengan merancang evaluasi dengan menggunakan aplikasi kahoot. Kahoot adalah permainan online yang dikembangkan untuk menjawab segala tantangan dalam proses belajar sebagaimana yang telah dipaparkan (Irwan,dkk, 2019). Beberapa kelebihan Kahoot adalah dapat dimainkan di laptop maupun smartphone, serta dapat menghadirkan suasana kuis yang menyenangkan. Melalui aplikasi

Kahoot, guru dapat memberikan materi melalui soal-soal dalam sebuah quiz yang meminta respon siswa untuk menjawab dan diberikan skor.(Ilmiyah \& Sumbawati, 2019). Selain itu soal-soal yang ada pada Kahoot memiliki alokasi waktu yang dapat di sesuaikan dengan tingkat kesulitan soal. Pada aplikasi Kahoot juga disertai musik yang dapat membangkitkan semangat bagi peserta didik sehingga dapat meningkatkan hasil belajar peserta didik

Penelitian mengenai penggunaan Kahoot pada pembelajaran diantaranya dilakukan oleh Wigati (2019). Berdasarkan penelitian tersebut menunjukan media Kahoot dapat meningkatkan hasil belajar.

Penelitian yang dilakukan oleh Perkasa (2019) menunjukkan peggunaan multimedia interaktif Kahoot dapat meningkatkan hasil belajar siswa dengan besarnya pengaruh multimedia interaktif Kahoot terhadap hasil belajar peserta didik.

Berdasarkan uraian di atas penulis mencoba melakukan penelitian dengan judul Peningatan hasil belajar Tema 3 Tugasku sehari- hari pada siswa kelas II Melalui Aplikasi Kahoot. Tujuan penelitian ini adalah meningkatkan hasil belajar tematik tema 3 Tugasku sehari-hari

\section{METODE}

Penelitian ini merupakan penelitian tindakan kelas (PTK) yang dilaksanakan dalam 3 siklus. Penelitian dilakukan dalam tiga siklus. Tiap siklus terdiri dari empat tahapan yaitu perencanaan, pelaksanaan, obsevasi, dan refleksi. Penelitian ini dilaksanakan pada siswa kelas II di SD Negeri Margasari 03 Kecamatan Margasari Kabupaten Tegal dengan jumlah siswa 29 siswa. 
Teknik pengumpulan data yang di gunakan dalam penelitian ini adalah tes ulangan harian yang digunakan untuk mendapatkan data tentang hasil belajar Tematik Tema 3 Tugasku sehari hari. Instrumen pengumpulan data dalam penelitian ini yang digunakan adalah butir soal tes formatif/ ulangan harian. Analisis data yang di gunakan dalam penelitian ini adalah analisis deskriptif komparatif untuk membandingkan hasil belajar melalui tes formatif/nilai ulangan harian antar siklus.

\section{HASIL DAN PEMBAHASAN}

Hasil Penelitian menunjukkan bahwa penggunaan aplikasi Kahoot untuk evaluasi dapat meningkatkan hasil belajar Tema 3 Tugasku sehari- hari pada siswa kelas II SD Negeri Margasari 03 Tahun Pelajaran 2020/2021. Evaluasi diberikan setelah selesai pembelajaran. Pada penilaian sebelumnya hanya 17 dari 29 siswa yang mencapai KKM dengan persentase ketuntasan $58 \%$. Setelah dilakukan tindakan, jumlah siswa tuntas meningkat menjadi 22 siswa pada siklus I, Pada siklus II terjadi peningkatan kembali dengan siswa tuntas menjadi 24 siswa, dan mengalami peningkatan kembali pada siklus III dengan jumlah siswa tuntas 26 siswa. Peningkatan hasil belajar tersebut dapat dilihat pada tabel berikut ini.

Tabel 1. Peningkatan Hasil Belajar

\begin{tabular}{|l|l|l|l|l|}
\hline No & Kondisi & $\begin{array}{c}\text { Jumlah } \\
\text { Siswa } \\
\text { Tuntas }\end{array}$ & $\begin{array}{c}\text { Nilai Rata- } \\
\text { rata }\end{array}$ & $\begin{array}{l}\text { Persentase } \\
\text { Ketuntasan }\end{array}$ \\
\hline 1 & $\begin{array}{l}\text { Kondisi } \\
\text { awal }\end{array}$ & 17 & 67 & $58 \%$ \\
\hline 2 & Siklus I & 22 & 76 & $72 \%$ \\
\hline 3 & Siklus II & 24 & 80 & $83 \%$ \\
\hline 4 & Siklus III & 26 & 84 & $90 \%$ \\
\hline
\end{tabular}

Berdasarkan data di atas, nilai rata -rata hasil belajar siswa mengalami peningkatan pada siklus I 76 meningkat menjadi 80 pada siklus II dan meningkat menjadi 84 pada siklus III. Ketuntasan belajar klasikal pada siklus I $72 \%$ meningkat menjadi $83 \%$ pada siklus II dan meningkat menjadi $90 \%$ pada siklus III.

Pada setiap siklus menggunakan jenis permainan quiz dikarenakan permainan tersebut tergolong mudah untuk siswa kelas II SD. Penerapan penggunaan kahoot pada penelitian ini guru membuat soal kahoot mode assign kemudian memberikan PIN pada siswa sehingga siswa dapat memainkannya kapanpun dan dimanapun. Penggunaan kahoot dalam evaluasi pembelajaran daring dilaksanakan agar siswa merasa tertarik dan tertantang dalam mengerjakan evaluasi sehingga hasil belajar dapat meningkat.

Berdasarkan hasil pembahasan dapat disimpulkan bahwa penggunaan Kahoot dapat meningkatkan hasil belajar siswa pada ema 3 Tugasku sehari- hari Subtema 3 Tugasku sebagai umat beragama. Hal ini sejalan dengan penelitian yang dilakukan oleh Kurniawati (2019) bahwa penggunaan Kahoot sebagai alat evaluasi berpengaruh terhadap peningkatan hasil belajar. 


\section{SIMPULAN}

Berdasarkan hasil penelitian yang dilakukan dapat disimpulkan penggunaan aplikasi Kahoot dapat meningkatkan hasil belajar siswa pada Tema 3 Tugasku seharihari Subtema 3 Tugasku sebagai umat beragama pada siswa kelas 2 SD Negeri Margasari 03 Tahun pelajaran 2020/2021, yang ditandai dengan peningkatan persentase ketuntasan belajar $72 \%$ pada siklus I, meningkat menjadi $83 \%$ pada siklus II, dan meningkat menjadi $90 \%$ pada siklus III.

\section{DAFTAR PUSTAKA}

Ilmiyah, N.H \& Sumbawati M.S. (2019). Pengaruh Media Kahoot dan Motivasi Belajar Terhadap Hasil Belajar Siswa https://journal.unesa.ac.id/index.php/jieet/article/view/5086 , 3(1)

Irwan,dkk. (2019), Efektifitas Penggunaan Kahoot! untuk Meningkatkan Hasil Belajar Siswa [Effectiveness of Using Kahoot! to Improve Student Learning Outcomes]. https://www.researchgate.net/publication/332503857_Efektifitas_Penggunaan_K ahoot_untuk_Meningkatkan_Hasil_Belajar_Siswa_Effectiveness_of_Using_Kaho ot_to_Improve_Student_Learning_Outcomes

Kurniawati, C.A.S (2019). Implementasi Media Kahoot sebagai alat evaluasi untuk meningkatkan hasil belajar siswa SD Negeri I Kerjo Lor Ngadirojo Wonogiri. http://digilib.uin-suka.ac.id/37270/

Perkasa, T.P. (2019) Pengaruh Penggunaan Multimedia Interaktif "KAhoot" Terhadap Hasil Belajar Peserta Didik Sekolah Dasar (Penelitian Kuasi Eksperimen di kelas V SD Negeri Giriharja 01 Tahun Ajaran 2019/2020). http://repository.unpas.ac.id/46423/

Wigati S, 2019, Penggunaan Media Game Kahoot untuk meningkatkan hasil dan minat belajar matematika, https://www.researchgate.net/publication/338295662_PENGGUNAAN_MEDIA_G AME_KAHOOT_UNTUK_MENINGKATKAN_HASIL_DAN_MINAT_ BELAJAR_MATEMATIKA 